\title{
Enhanced Antioxidant Capacity of Fresh Blueberries by Pulsed Light Treatment
}

\author{
Cheryl Rock ${ }^{1}$, Senem Guner ${ }^{2}$, Wade Yang ${ }^{2}$, Liwei Gu ${ }^{2}$, Susan Percival ${ }^{2} \&$ Esmeralda Salcido $^{1}$ \\ ${ }^{1}$ California State University, United States \\ ${ }^{2}$ University of Florida, United States \\ Correspondence: Cheryl Rock, California State University, United States. E-mail: cheryl.rock@csulb.edu
}

\author{
Received: February 1, 2015 Accepted: May 26, 2015 Online Published: August 31, 2015 \\ doi:10.5539/jfr.v4n5p89 URL: http://dx.doi.org/10.5539/jfr.v4n5p89
}

\begin{abstract}
As a novel technology for food safety risk mitigation, pulsed light (PL) has been shown effective in surface decontamination of fresh blueberries in literature. However, little is known about the effects of PL on the antioxidant capacity and quality characteristics of fresh blueberries. Fresh blueberries from a local farm were treated with PL for 30, 60, 90 and $120 \mathrm{~s}$. Results show that PL exposure enhanced the antioxidant activity (ORAC) and total phenolic content of fresh blueberries 50 and $48 \%$ respectively, relative to the control. Pulsed light also significantly increased the total anthocyanin contents, which may be due to the upregulation of Phenylalanine Ammonium Lyase (PAL) enzymes. There was no significant difference $(P \leq 0.05)$ in the soluble solids, $\mathrm{pH}$, titratable acidity, firmness, color and mass of the fresh blueberries within $120 \mathrm{~s}$ PL exposure. In conclusion, PL illumination enhanced the antioxidant capacity of fresh blueberries while maintaining other quality characteristics.
\end{abstract}

Keywords: nonthermal, phytochemical, anthocyanins, phenylalanine ammonium lyase, phenolics, flavonoids

\section{Introduction}

Blueberries (Vaccinium corymbosum) are a rich source of phenolic compounds, including quercetin, procyanidins and flavonoids (Sellappan et al., 2002). Anthocyanins are the major water-soluble flavonoids in blueberries, giving the red, purple and blue color to many fruits and vegetables (Espín et al., 2007). Additionally they are considered biologically active compounds exhibiting a wide range of health benefits, e.g., antioxidant (Cao et al., 1997), antifungal (Benkeblia, 2004), and anti-carcinogenic properties (Ames, 1983). It is well established that free radicals play an important role in the etiology of many diseases, such as cancer, vascular and neurodegenerative disease (Jacob, 1995). Espín et al. (2007) reported that anthocyanins and anthocyanin-rich berries or plant extracts exhibited a wide range of potential health benefits in both human and animal studies. These benefits are attributed to their free radical scavenging properties and their unique capacity in absorbing oxygen radicals, and chelating metal ions which are strong oxidizing agents of deoxyribonucleic acid (DNA) (Halliwell, 1995).

Among other fresh fruits, blueberries are regarded as the agricultural commodity rating the highest in antioxidant capacity, which warrants their potential health benefits and status as a functional food (U.S Highbush Blueberry Council, 2011). It has been estimated that U.S. per capita fresh blueberry consumption would increase $65 \%$ from estimated $0.756 \mathrm{~kg}$ in 2008 to $1.25 \mathrm{~kg}$ by 2015 (U.S Highbush Blueberry Council, 2009). This predicted increase in consumption is also accompanied with a demand for blueberry products with minimal changes in quality, nutritional profile and enhanced shelf life.

Pulsed light (PL) (100-1100 nm) is a novel food processing technology, which has shown effectiveness in decontaminating food surfaces, packaging materials and small berries and fruits including blueberries. To illustrate, Bialka and Demirci (2007) reported that maximum reductions in pathogenic bacteria such as $E$. coli O157: $\mathrm{H7}$ and Salmonella were 4.3 and $2.9 \log _{10} \mathrm{CFU} / \mathrm{g}$ respectively, in fresh blueberries using PL. Additionally, Krishnamurthy et al. (2008), have reported on the effects of continuous ultraviolet (UV) light (100-400 nm), primarily UV-C (100-290 nm), which has been predominantly used for its germicidal properties. However, the effects of PL on fresh blueberries antioxidant properties, is little known. The efficacy of PL can be attributed to its photothermal, photochemical and photophysical effects. We hypothesized that similar to UV light, PL exposure 
might have enhancing effects on the antioxidant potency of fresh blueberries, besides its preservation on fruit quality. The most studied enzymes associated with secondary metabolite synthesis (anthocyanins and polyphenolics) in plants are PALs. Synthesis of these metabolites catalyzed by PAL is achieved through several pathways (Pentose Phosphate, Shikimate, Phenylpropanoid and Flavonoid), which may function synergistically (Cao et al., 2010) to counteract the damaging effects external stressors on cell components such as UV light. Therefore, the objective of this study was to investigate the effects of PL on the total antioxidant activity, polyphenolic contents, PAL enzyme, physiochemical attributes ( $\mathrm{pH}, \mathrm{TA}, \mathrm{SS}$ ), and quality (color, texture) of fresh blueberries.

\section{Method}

\subsection{Sample Preparation}

Early season (May - June) highbush blueberries were handpicked from a local farm (Gainesville, FL, USA) at commercial maturity stage from trees within the same grove. The fruits were stored at $4{ }^{\circ} \mathrm{C}$ for 1 day, and prior to $\mathrm{PL}$ treatment, they were sorted to remove impurities, washed and left to dry at ambient temperature $\approx \approx$ $20-25^{\circ} \mathrm{C}$ ) for 1 day.

\subsection{Pulsed Light Treatment}

Blueberries $(20 \pm 1 \mathrm{~g})$ were placed in $70 \mathrm{~mL}$ aluminum dishes. Samples were transferred to the Xenon PL system model LH840 LMP HSG (Xenon Corporation, Wilmington, MA, USA) and treated at 3 pulses/s for 30, 60, 90 and $120 \mathrm{~s}$ at a distance of $13 \mathrm{~cm}$ from the lamp in stationary mode. The initial and final surface temperature of the samples was measured using a handheld infrared thermometer (Omega OS423-LS, Omega Technologies, Stamford, CT, USA).

\subsection{Antioxidant Capacity}

The blueberry samples were macerated using a homogenizer and extracted with a solvent mixture $(20 \mathrm{~mL}) \mathrm{of}$ acetone/water/acetic acid (70:29.9:0.1, v/v/v), followed by sonication (Zenith ultrasonic bath, $25 \mathrm{kHz}, 1350 \mathrm{~W}$, Zenith Manufacturing and Chemical Corp, Norwood, NJ, USA) for $30 \mathrm{~min}$. The extracts were centrifuged $\left(12,000 \mathrm{G}[10,000 \mathrm{rpm}], 45 \mathrm{~min}, 4^{\circ} \mathrm{C}\right)$ and the supernatant was collected for oxygen radical absorbance capacity (ORAC) analysis as described by (Huang et al., 2002). Fifty $\mu \mathrm{L}$ ORAC phosphate buffer (PB) (75 mM ORAC-PB) and samples were added to a 96-well black plate (Fisher Scientific, Pittsburgh, PA, USA), followed by addition of $100 \mu \mathrm{L}$ fluorescein $(20 \mathrm{mM})$ solution. The mixture was incubated $\left(37^{\circ} \mathrm{C}, 10 \mathrm{~min}\right)$ before adding the peroxyl radical generator 2,2'azobis (2-amidinopropane) dihydrochloride (140 mM AAPH). The rate of fluorescence decay ( $485 \mathrm{~nm}$ excitation and $530 \mathrm{~nm}$ emissions for $1 \mathrm{~min}$ intervals for $40 \mathrm{~min}$ ) was monitored by using a microplate reader (Spectra Max Gemini XPS Molecular Devices, Sunnyvale, CA, USA). The rate of florescent decay was then calculated using the area under the fluorescent decay using the Trolox standard curve. Antioxidant capacities were expressed as $\mu \mathrm{mol}$ trolox equivalents (TE)/g extracted samples.

\subsection{Phenylalanine Ammonia Lyase (PAL) Enzyme}

Under minimal light conditions, enzyme extraction was performed using untreated and PL treated blueberry samples $(4 \mathrm{~g})$ added to polyvinylpolypyrrolidone (PVP) $(0.4 \mathrm{~g})$ and homogenized into $16 \mathrm{ml}$ of ice-cold borate buffer (50 mM borate; $400 \mu \mathrm{L} / \mathrm{L} \beta$-mercaptoethanol; $\mathrm{pH} 8.5$ ) (Velazquez et al., 2011). The homogenates were subsequently centrifuged $\left(12,000 \mathrm{G}[10,000 \mathrm{rpm}], 30 \mathrm{~min}, 4{ }^{\circ} \mathrm{C}\right)$, and supernatants maintained at $4{ }^{\circ} \mathrm{C}$ and promptly assayed. To a 96 well clear plate, $235 \mu \mathrm{L}$ borate buffer, $35 \mu \mathrm{L}$ L-phenylalanine substrate solution (100 $\mathrm{mM}$ ) and $80 \mu \mathrm{L}$ of PAL extract were added. Using a microplate reader (Synergy HT, Biotek Instruments INC, Vermont, USA) spectrometric readings $(290 \mathrm{~nm})$ were taken before and after $1 \mathrm{~h}$ of incubation $\left(40^{\circ} \mathrm{C}\right)$ versus a reagent blank. The PAL activity (mg of t-cinnamic acid/ h) was calculated using cinnamic acid as a standard $(0.02-0.10 \mathrm{mg} / \mathrm{mL})$. L-Phenylalanine substrate solution was prepared in nanopure water before each assay.

\subsection{Total Polyphenolics}

Polyphenolic compounds were extracted as described by Kim et al. (2003). The sample mixture (20 g sample, $80 \%$ of $200 \mathrm{ml}$ methanol, $\mathrm{v} / \mathrm{v})$ was sonicated for $30 \mathrm{~min}$ and centrifuged $\left(12,000 \mathrm{G}, 50 \mathrm{~min}, 4^{\circ} \mathrm{C}\right)$. The solvent was evaporated using a Büchi Rotavapor 2025 (Gardner Denver Thomas, Inc., Niles, IL, USA) at $40{ }^{\circ} \mathrm{C}$ and the phenolic extracts were stored at $-20{ }^{\circ} \mathrm{C}$ until further analysis. To a 96 well clear plate (Fisher Scientific, Pittsburgh, PA, USA), $12.5 \mu \mathrm{L}$ of $2 \mathrm{M}$ Folin-Ciocalteu phenol reagent was added to $50 \mu \mathrm{L}$ of deionized distilled water $\left(\mathrm{ddH}_{2} \mathrm{O}\right)$ and $12.5 \mu \mathrm{L}$ of sample. After $5 \mathrm{~min}, 7 \%$ sodium carbonate $\left(\mathrm{Na}_{2} \mathrm{CO}_{3}\right)$ solution $(125 \mu \mathrm{L})$ was added to the mixture and incubated $\left(90 \mathrm{~min}, 25^{\circ} \mathrm{C}\right)$. Sample absorbance was measured at $750 \mathrm{~nm}$ using a microplate reader. A standard curve was developed using gallic acid and the concentration was expressed as $\mathrm{mg}$ gallic acid equivalents (GAE)/g fruit on a wet basis. 


\subsection{Total Flavonoids}

A standard colorimetric assay (Kim et al., 2003) with slight modifications was used to quantify total flavonoid content. $25 \mu \mathrm{L}$ of the sample along with $125 \mu \mathrm{L}$ of $\mathrm{ddH}_{2} \mathrm{O}$ was added to a 96 well clear plate. Subsequently, $7.5 \mu \mathrm{L}$ of $5 \%$ sodium nitrate $\left(\mathrm{NaNO}_{2}\right)$ was added to the mixture and allowed to stand for $5 \mathrm{~min}$. Fifteen microliters of $10 \%$ aluminum chloride $\left(\mathrm{AlCl}_{3}\right)$ was added to the mixture and incubated at ambient temperature for an additional $5 \mathrm{~min}$. Following that, $50 \mu \mathrm{L}$ of sodium hydroxide $(1 \mathrm{M}, \mathrm{NaOH})$ was added to the mixture and immediately diluted by the addition of $27.5 \mu \mathrm{L}$ of $\mathrm{ddH}_{2} \mathrm{O}$. The absorbance of the mixture was measured at a wavelength of $510 \mathrm{~nm}$ against a reagent blank and compared to a catechin standard using a microplate reader. The total flavonoids was calculated as $\mathrm{mg}$ of catechin equivalents $(\mathrm{CE}) / \mathrm{g}$ of fruit.

\subsection{Total Anthocyanins}

Two buffer systems (pH differential method) composed of potassium chloride $(\mathrm{KCl})(\mathrm{pH} 1.0,0.025 \mathrm{M})$ and sodium acetate $\left(\mathrm{NaC}_{2} \mathrm{H}_{3} \mathrm{O}_{2}\right)(\mathrm{pH} 4.5,0.4 \mathrm{M})$ were used to perform anthocyanin analysis as described by Benvenuti et al. (2004). An aliquot of the blueberry extracts were simultaneously diluted (1:10) and adjusted to $\mathrm{pH} 1.0 \mathrm{and} \mathrm{pH}$ 4.5 using the respective buffers, and incubated at ambient temperature for $20 \mathrm{~min}$. Absorbance was measured at each pH using a UV/VIS spectrophotometer (Beckman Coulter, Du 730, Life Sciences UV/VIS, Lawrence, KS, USA) at 510 and $700 \mathrm{~nm}$ respectively. Results were calculated using equations 1 and 2 below and expressed as $\mathrm{mg}$ cyanidin-3-glucoside (predominant anthocyanin) per $\mathrm{g}$ fruit using the corresponding MW (molecular weight [449.2]) and $\varepsilon$ (molar absorptivity [26 900]). The acronyms A (absorbance) and DF (dilution factor) also denote the elements used in the equations below (Sellappan et al., 2002).

$$
\begin{gathered}
A=\left(\mathrm{A}_{510 \mathrm{~nm}}-\mathrm{A}_{700 \mathrm{~nm}}\right)_{\mathrm{pH} 1.0}-\left(\mathrm{A}_{510 \mathrm{~nm}}-\mathrm{A}_{700 \mathrm{~nm}}\right)_{\mathrm{pH} 4.5} \\
\text { Anthocyanins }=A \times \mathrm{MW} \times \mathrm{DF} \times 1000 /(\varepsilon \times 1)
\end{gathered}
$$

\subsection{Color Analysis}

The blueberry color was measured using a machine vision system (Nikon D200 digital camera housed in a light box $[42.5 \mathrm{~cm}(\mathrm{~W}) \times 61.0 \mathrm{~cm}(\mathrm{~L}) \times 78.1 \mathrm{~cm}(\mathrm{H})]$ (Wallat 2002). The camera (focal light, $35 \mathrm{~mm}$; polarization, 18.44 $\mathrm{mm}$ ) was controlled by the LensEye software (Engineering and Cybersolutions Inc. Gainesville, FL, USA) and calibrated with a standard blue tile (L: 58.24; $\mathrm{a}^{*}:-4.74 ; \mathrm{b}^{*}:$-42.44) (Labsphere, North Sutton, NH, USA).

\subsection{Texture Analysis}

A texture analyzer (TA.XT Plus, Texture Technologies Corporation, Scarsdale, NY, USA) was utilized to evaluate the firmness of the blueberries by the compression test. The firmness was measured at the surface of the horizontally aligned blueberry to a total distance of $5 \mathrm{~mm}$, using a TA-212 5/16" diameter probe (radius of curvature 13/64") and subjecting $50 \mathrm{~kg}$ of force a speed of $2.0 \mathrm{~mm} / \mathrm{s}$.

\subsection{Soluble Solids (SS), $\mathrm{pH}$ and Titratable Acidity (TA)}

Soluble solids were determined using a digital refractometer (Leica Mark II Abbe Refractometer, Buffalo, NY, USA) and expressed as $\mathrm{Brix}^{\circ}$. The sample $\mathrm{pH}$ was measured using a pH meter (Fisher Scientific Accumet ${ }^{\circledR}$ Basic AB15/157, Pittsburgh, PA, USA). For TA, $10 \mathrm{~g}$ of blueberry samples was macerated into $50 \mathrm{~mL}$ of $\mathrm{ddH}_{2} \mathrm{O}$ and titrated with sodium hydroxide $(\mathrm{NaOH}, 0.1 \mathrm{M})$ until a $\mathrm{pH}$ of 8.2 was obtained. The TA results were reported as \% equivalent weight of malic acid/g fruit.

\subsection{Statistical Analysis}

The data obtained was analyzed using a statistical analysis system (SAS 9.1). Analysis of variance (one-way ANOVA) was performed and the significant differences in the means were separated using the Tukey's studentized range test. The data was tabulated as an average of triplicates \pm standard deviation, and the level of significance was determined at $P \leq 0.05$.

\section{Results and Discussion}

\subsection{Antioxidant Capacity}

No significant differences $(P \leq 0.05)$ were observed in ORAC values between control and PL treatments of 60 and 90 s. However, significant differences $(P \leq 0.05)$ existed between control 30 and $120 \mathrm{~s}$ (Table 1$)$. There was nearly a $75 \%$ increase in ORAC values (30 s) relative to control. Similarly, Wang et al. (2009) evaluated the antioxidant capacity and individual flavonoid compounds in blueberries exposed to UV-C illumination for 1, 5, 10 and $15 \mathrm{~min}$. They found an increase in ORAC values compared to the control. Their values ranged from a low of $40.4 \pm 3.2$ (Control) to a high of $59.6 \pm 2.0 \mu \mathrm{mol} \mathrm{TE} / \mathrm{g}$ (UV-C illumination at $6.45 \mathrm{~kJ} \mathrm{~m}^{-2}$ which was lower than 
our reported values. Our results indicated that PL is also capable of increasing the antioxidant content of blueberries, which was achieved at much shorter exposure times than those of UV-C illumination.

Table 1. Antioxidant capacity of pulsed light treated blueberries expressed as the oxygen radical absorbance capacity (ORAC)

\begin{tabular}{ll}
\hline Treatment & $\mu$ moL Trolox eq/g fresh weight \\
\hline Control & $119.2 \pm 4.82 \mathrm{~b}$ \\
PL $30 \mathrm{~s}$ & $131.7 \pm 14.7 \mathrm{a}$ \\
PL $60 \mathrm{~s}$ & $121.4 \pm 14.7 \mathrm{~b}$ \\
PL $90 \mathrm{~s}$ & $117.4 \pm 5.14 \mathrm{~b}$ \\
PL $120 \mathrm{~s}$ & $97.9 \pm 4.14 \mathrm{c}$
\end{tabular}

Means (in columns) with the same letter are not significantly different according to the Tukey's studentized Range Test $P \leq 0.05$. Data are expressed as mean \pm standard deviation (SD).

\subsection{Phenylalanine Ammonium Lyase (PAL)}

In our study, the stimulatory effect of PL on PAL activity was investigated. The highest response was observed at a treatment time of $120 \mathrm{~s}$ (Figure 1). This may account for the increase in the antioxidant capacity and anthocyanin content of the blueberries as observed in our study. Previous research (Dixon \& Paiva, 1995) indicates that PAL are photo induced by intense or UV light as a defensive response to attenuate its intensity which may damage photosynthetic cells. In this experiment, reduced enzymatic activity was observed at 90s. While an increase was expected as observed in blueberries treated with PL for 30 and 60s, the disparity in the enzyme activity could have been attributed to the enzymes biosynthesis pathways where tyrosine instead of phenylalanine could have been the main substrate resulting in another end product mainly coumaric acid instead of cinnamic acid (Cao et al., 2010).

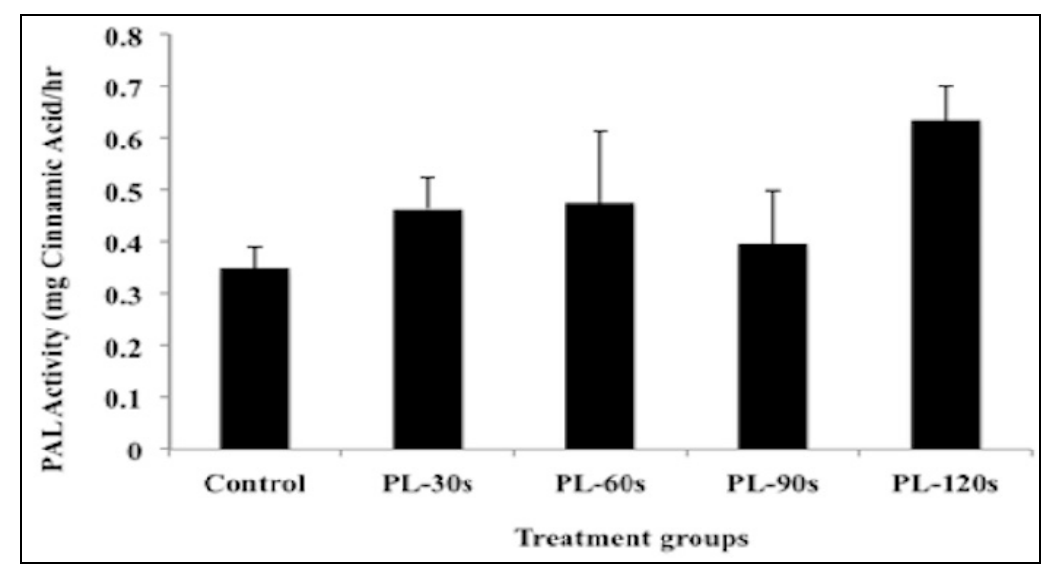

Figure 1. Stimulatory Effect of PL illumination on PAL activity

\subsection{Total Phenolics}

There was no significant difference $(P \leq 0.05)$ in total phenolics between PL $30 \mathrm{~s}$ and control. A significant increase $(P \leq 0.05)$ was found for PL 60 and $90 \mathrm{~s}$ compared to control (Table 2). The highest percentage increase relative to control was $48 \%$ at PL $90 \mathrm{~s}$, indicating that PL had a significant $(P \leq 0.05)$ enhancing effect on total phenolics within $90 \mathrm{~s}$ exposure. However, a decrease in total phenolics was observed at PL $120 \mathrm{~s}$, which had a significantly $(P \leq 0.05)$ lower value than PL $90 \mathrm{~s}$, but comparable with control. Phenolic decrease in our experiments may be attributed to increased polyphenoloxidase (PPO) activity, which may have resulted in oxidation of these compounds as suggested by Moreno et al. (2007). According to Agarwal (2007), enzymes such as PPO function as antioxidants against oxidative stress, induced by the UV-B spectrum of PL, which may have upregulated their activity resulting in the oxidation of phenols to quinones. However, the fact that the total 
phenolics at $120 \mathrm{~s}$ was not significantly different $(P \leq 0.05)$ from control, suggested that PL did not have a degradative effect on the total phenolic content. Similar trends were observed by Wang et al. (2009). They found an increased level of total phenolics proportionate to the time of UV-C exposure. They reported a low of $3.12 \pm$ 0.06 (control) to a high of $4.97 \pm 0.09 \mathrm{mg} \mathrm{GAE} / \mathrm{g}$ at the energy strength of $2.15 \mathrm{~kJ} \mathrm{~m}^{-2}$.

\subsection{Total Flavonoids}

The flavonoid content significantly $(\mathrm{P} \leq 0.05)$ increased in all PL treated samples after $30 \mathrm{~s}, 60 \mathrm{~s}, 90 \mathrm{~s}$ and $120 \mathrm{~s}$ of PUV exposure as compared to the control (Table 2). Our values ranged from a low of $0.147 \pm 0.01 \mathrm{mg} / \mathrm{CE} / \mathrm{g}$ fruit (Control) to a high of $0.197 \pm 0.02 \mathrm{mg} / \mathrm{CE} / \mathrm{g}$ fruit (PUV 30s). However, although there was an increase in flavonoid content, there were no significant $(\mathrm{P} \leq 0.05)$ differences observed among the samples treated with PUV at $60 \mathrm{~s}, 90 \mathrm{~s}$ and $120 \mathrm{~s}$, showing that exposure after $30 \mathrm{~s}$ did not significantly increase flavonoid content. The main underlying mechanism for this phenomenon was explained by Wang et al. (2009). They mentioned that at high doses of UV light might result in too much stress resulting in injury consequently inhibiting further flavonoid synthesis.

\subsection{Total Anthocyanins}

It was observed that PL stimulated an increase in blueberry anthocyanins, which ranged from a low of $0.738 \mathrm{mg} / \mathrm{g}$ \pm 0.27 (control) to a high of $0.962 \mathrm{mg} / \mathrm{g} \pm 0.24$ (PL $120 \mathrm{~s}$ ) (Table 2). Significant differences $(P \leq 0.05$ ) were observed in all PL treated samples relative to control, however, no significant differences were observed among the samples PL treated for 30,60 and $90 \mathrm{~s}$. As alluded to previously, PAL enzymes are associated with the biosynthesis of anthocyanins. This provides direct evidence as to why there was an increase in the anthocyanin content of blueberries as observed in our study. According to researchers (Heredia \& Cineros-Zevallos, 2009), the upregulation of polyphenolic compounds such as anthocyanins may be a major defense mechanism inducible in blueberries due to PL illumination as an external stressor.

Table 2. Effect of pulsed light on total phenolics, flavonoids and anthocyanin content in blueberries

\begin{tabular}{cccc}
\hline Treatment & Phenolics (mg/GAE/g Fruit) & Flavonoids (mg/CE/g Fruit) & Anthocyanins (mg/g Fruit) \\
\hline Control & $2.08 \pm 0.84 \mathrm{a}$ & $0.147 \pm 0.01 \mathrm{c}$ & $0.738 \pm 0.28 \mathrm{c}$ \\
PUV $30 \mathrm{~s}$ & $2.46 \pm 1.42 \mathrm{a}$ & $0.196 \pm 0.02 \mathrm{a}$ & $0.916 \pm 0.16 \mathrm{~b}$ \\
PUV $60 \mathrm{~s}$ & $3.05 \pm 0.22 \mathrm{~b}$ & $0.180 \pm 0.01 \mathrm{~b}$ & $0.882 \pm 0.11 \mathrm{~b}$ \\
PUV $90 \mathrm{~s}$ & $3.07 \pm 0.47 \mathrm{~b}$ & $0.183 \pm 0.02 \mathrm{~b}$ & $0.851 \pm 0.13 \mathrm{~b}$ \\
PUV $120 \mathrm{~s}$ & $2.24 \pm 0.44 \mathrm{a}$ & $0.190 \pm 0.02 \mathrm{~b}$ & $0.962 \pm 0.24 \mathrm{a}$
\end{tabular}

Means (in columns) with the same letter are not significantly different according to the Tukey's studentized Range Test $P \leq 0.05$. Data are expressed as mean \pm standard deviation (SD).

\subsection{Soluble Solids}

Although the mean SS in blueberries ranged from a high of $11.67{ }^{\circ} \mathrm{Brix} \pm 0.04$ at PL $30 \mathrm{~s}$ to a low of $10.86^{\circ} \mathrm{Brix} \pm 0.04$ at PL $60 \mathrm{~s}$ (Table 3), there was no significant difference $(P \leq 0.05)$ of SS among all PL treatment groups compared to control. This may suggest that PL did not have an effect on SS metabolism, which may also vary according to blueberry cultivar. Perkins-Veazie et al. (2008) also reported that exposure to UV-C light did not affect SS content, but slight variations may be attributed to cultivar and storage conditions.

$3.7 \mathrm{pH}$

A stable $\mathrm{pH}$ is very important to blueberries during processing and post-processing handling, as its hue and color is highly dependent on the $\mathrm{pH}$ change. This is because anthocyanin pigments may undergo reversible transformations with the change of $\mathrm{pH}$ (Tomas-Barberan \& Espin, 2001). Table 3 shows the average $\mathrm{pH}$ values after the blueberries were PL treated compared to control. The $\mathrm{pH}$ value ranged from a low of $3.07 \pm 0.02$ at PL $90 \mathrm{~s}$ to a high of $3.21 \pm 0.04$ at PL $120 \mathrm{~s}$. However, in general there was no significant difference $(P \leq 0.05)$ in $\mathrm{pH}$ value among the PL treated blueberries and no difference either compared to control. This indicates that PL exposure up to $120 \mathrm{~s}$ did not have an effect on the $\mathrm{pH}$ of fresh blueberries. A similar trend was observed in a study performed by Perkins-Veazie et al. (2008). They reported that after the UV-C exposure (1-15 min, $8 \mathrm{~cm}$ from UV lamp), there was a slight increase in blueberry $\mathrm{pH}$ values, but there was no significant effect $(P \leq 0.05)$. 


\subsection{Titratable Acidity}

The TA values in Table 3 ranged between $0.40 \% \pm 0.13$ at PL $120 \mathrm{~s}$ and $0.47 \% \pm 0.15$ in the control. Our results were comparable with those of Perkins-Veazie et al. (2008), who reported 0.44 and $0.54 \%$ malic acid equivalents in the Collins and Bluecrop variety, respectively, after UV-C treatments. Our results showed no significant effect $(P \leq 0.05)$ of PL on TA even after exposure for $120 \mathrm{~s}$, which may imply that PL (within $120 \mathrm{~s}$ ) had no degradative effects.

\subsection{Texture Analysis}

As an important rheological parameter for textural quality, firmness has been shown in literature as a standard trait to reflect the quality of fresh fruits and vegetables. As shown in Table 3, the firmness values of PL treated vs. untreated (control) blueberries showed no significant difference $(P \leq 0.05)$. The firmness values ranged from a low $8.82 \pm 0.05$ Newtons $(\mathrm{N})$ in blueberries PL treated for $120 \mathrm{~s}$ to a high of $10.29 \pm 0.04 \mathrm{~N}$ in untreated blueberries (control). Our results suggest that PL treatment in the time range tested did not have an effect on the firmness of the blueberries. In contrast, a study by Silva et al. (2005) investigating the variations in the physiochemical (pectin, $\mathrm{pH}, \mathrm{TA}$, fiber, skin toughness) observed differences in the firmness in several cultivars of blueberries. They found that the texture ranged from a high of $7.28 \mathrm{~N}$ to a low of $3.58 \mathrm{~N}$ in the Climax and Jersey cultivars, respectively. Their values were lower than those reported in our study, which may be attributed to varietal differences.

Table 3. Physiochemical properties of pulsed light treated blueberries.

\begin{tabular}{clccc}
\hline Treatment & $\mathrm{pH}$ & Titratable acidity $(\%$ malic acid) & Soluble solids ( ${ }^{\circ}$ Brix) & Firmness (Newtons) \\
\hline Control & $3.16 \pm 0.06 \mathrm{a}$ & $0.48 \pm 0.15 \mathrm{a}$ & $11.6 \pm 0.5 \mathrm{a}$ & $10.30 \pm 0.03 \mathrm{a}$ \\
PL 30 s & $3.21 \pm 0.04 \mathrm{a}$ & $0.41 \pm 0.02 \mathrm{a}$ & $11.7 \pm 0.5 \mathrm{a}$ & $8.92 \pm 0.04 \mathrm{a}$ \\
PL $60 \mathrm{~s}$ & $3.13 \pm 0.04 \mathrm{a}$ & $0.41 \pm 0.11 \mathrm{a}$ & $10.9 \pm 0.2 \mathrm{a}$ & $9.32 \pm 0.05 \mathrm{a}$ \\
PL $90 \mathrm{~s}$ & $3.07 \pm 0.02 \mathrm{a}$ & $0.42 \pm 0.10 \mathrm{a}$ & $10.9 \pm 0.1 \mathrm{a}$ & $9.51 \pm 0.03 \mathrm{a}$ \\
PL $120 \mathrm{~s}$ & $3.21 \pm 0.03 \mathrm{a}$ & $0.40 \pm 0.13 \mathrm{a}$ & $11.4 \pm 0.4 \mathrm{a}$ & $8.83 \pm 0.05 \mathrm{a}$
\end{tabular}

Means (in columns) with same letter not significantly different according to the Tukey's Studentized Range Test $P \leq 0.05$. Data is expressed as mean \pm standard deviation (SD).

\subsection{Color Analysis}

Significant differences $(P \leq 0.05)$ were observed among all treatment groups in the degree of lightness $\left(\mathrm{L}^{*}\right)$, greenness $\left(a^{*}\right)$, and blueness $\left(b^{*}\right)$ values compared to the control (Table 4$)$. The $\mathrm{L}^{*}$ values indicated that the blueberries darkened in color after prolonged PL exposures. No significant differences $(P \leq 0.05)$ were observed between those treated for $30 \mathrm{~s}$ and $60 \mathrm{~s}$ relative to control. However, those treated for 90 and $120 \mathrm{~s}\left(\mathrm{~L}^{*}=17.23 \pm\right.$ $1.94,15.50 \pm 1.75$ respectively), were darkest in color as compared to control $\left(L^{*}=20.51 \pm 1.93\right)$ and other treatment groups. Overall, our results showed that PL decreased b* values (i.e., more dark blue) of the samples as compared to the control. A similar result was observed by Moreno et al. (2007) who investigated the effects of ionizing radiation $(0,1.1,1.6$ and $3.2 \mathrm{kGy})$ on blueberry color. With a higher dosage of irradiation, there was a decrease in the $b^{*}$ values resulting in darker fruit. They hypothesized that the darkening of the fruit color in the treated blueberries may be attributed to co-pigmentation where anthocyanins form complexes with flavonoid compounds, causing an increase in color intensity. As previously mentioned, other associative mechanisms during treatment could be the activation of enzymes (PAL) in the pentose phosphate, shikimate, phenylprenoid and flavonoid pathways, associated with the synthesis of anthocyanins that could act as UV screens to reduce the damaging effects of UV on the genetic materials in plant tissues (Tomas-Barberan \& Espin, 2001). Our results showed that there was an increase in PAL enzyme activity, indicated by the accumulation of cinnamic acid after PL treatments (Figure 1). These results suggest that exposure to PL might have resulted in the darkening of the fruits. 
Table 4. Effect of pulsed light treatment on blueberry color

\begin{tabular}{llll}
\hline Treatment & Lightness (L-) & Blueness (-b) & Greenness (-a) \\
\hline Control & $20.51 \pm 1.93 \mathrm{a}$ & $-7.29 \pm 0.93 \mathrm{c}$ & $-5.25 \pm 0.30 \mathrm{~b}$ \\
PL $30 \mathrm{~s}$ & $20.40 \pm 1.56 \mathrm{a}$ & $-6.76 \pm 0.39 \mathrm{c}$ & $-5.46 \pm 0.29 \mathrm{~b}$ \\
PL $60 \mathrm{~s}$ & $19.38 \pm 2.54 \mathrm{a}$ & $-6.12 \pm 1.12 \mathrm{~b}, \mathrm{c}$ & $-5.36 \pm 0.16 \mathrm{~b}$ \\
PL $90 \mathrm{~s}$ & $17.23 \pm 1.94 \mathrm{~b}$ & $-5.04 \pm 1.02 \mathrm{a}, \mathrm{b}$ & $-5.30 \pm 0.17 \mathrm{~b}$ \\
PL $120 \mathrm{~s}$ & $15.50 \pm 1.75 \mathrm{~b}$ & $-4.35 \pm 0.51 \mathrm{a}$ & $-4.52 \pm 0.69 \mathrm{a}$ \\
\hline
\end{tabular}

Means (in columns) with same letter not significantly different according to the Tukey's Studentized Range Test $P \leq 0.05$. Data are expressed as mean \pm standard deviation (SD).

\subsection{Temperature Rise}

Novel technologies such as PL have been used as an alternative to thermal processing of foods (Oms-Oliu et al., 2010). It is well known that foods treated with high temperatures are susceptible to thermal degradation, which may result in undesirable changes to their organoleptic and physiochemical properties. For PL, when the exposure time is short (e.g., seconds), temperature rise during the treatment is low, because the photothermal effect of PL is minimal; however, prolonged exposure (e.g., minutes) would result in temperature increase of the product (Shriver et al., 2011; Yang et al., 2011) as the photothermal effect is intensified and is attributed to the infrared portion of the PL spectra.

According to Table 5, the surface temperature ranged from a low of $22.5{ }^{\circ} \mathrm{C} \pm 0.7$ in untreated (control) blueberries to a high of $35.5^{\circ} \mathrm{C} \pm 1.2$ in PL treated blueberries for $120 \mathrm{~s}$. It is noted that there was a few seconds delay before the temperature reading, when the sample was removed from the treatment chamber upon completion of the PL treatment, so the instantaneous surface temperature could possibly be a bit higher. It was observed that the surface temperature was not significantly different $(P \leq 0.05)$ among control, PL 30 and 60, but significantly different after $90 \mathrm{~s}$ (Table 5).

Temperature rise to between $45{ }^{\circ} \mathrm{C}$ and $54{ }^{\circ} \mathrm{C}$ has been reported to improve sensory and nutritional quality of some horticulture products like tomato (Lurie \& others, 2006; Rajchl et al., 2009) or low-temperature storage quality (Vlachonasios et al., 2001) without damage to the product. In contrast, the recorded surface temperature of blueberries after $120 \mathrm{~s}$ PL exposure generally did not exceed $54{ }^{\circ} \mathrm{C}$, so there should not be any negative impact of the temperature rise on the blueberry quality, although no corresponding tests were conducted to verify such an inference in this study.

\subsection{Weight Loss}

Pulsed light treatment up to $120 \mathrm{~s}$ was found to cause no weight loss of the blueberries (Table 5). The initial mass was $20 \pm 1 \mathrm{~g}$ for each of the samples, and no mass changes were detected on the balance (accurate to $1 \mathrm{~g}$ ) for PL 30 to $120 \mathrm{~s}$. Since the evaporation of water from the fruit to the environment is the predominant cause for weight loss during processing (Yang et al., 2010; Duan et al., 2011), the temperature of the product needs to be high enough to initiate the phase change of water from liquid to vapor, before it could escape from the food matrix. As mentioned earlier, the temperature rise of the fresh blueberries after PL treatments up to $120 \mathrm{~s}$ was not significant in this study. This explains why no mass changes were recorded in this study.

Table 5. Effect of pulsed light on the surface temperature and mass of fresh blueberries. The initial mass (control) was set to $20 \mathrm{~g}$ with triplicate samples

\begin{tabular}{ll}
\hline Treatment & Temperature $\left({ }^{\circ} \mathrm{C}\right)$ \\
\hline Control & $22.5 \pm 0.7 \mathrm{~b}$ \\
PL $30 \mathrm{~s}$ & $23.0 \pm 0.4 \mathrm{~b}$ \\
PL $60 \mathrm{~s}$ & $25.1 \pm 0.3 \mathrm{~b}$ \\
PL $90 \mathrm{~s}$ & $32.7 \pm 0.7 \mathrm{a}$ \\
PL $120 \mathrm{~s}$ & $35.5 \pm 1.2 \mathrm{a}$ \\
\hline
\end{tabular}

Means (in columns) with same letter not significantly different according to the Tukey's Studentized Range Test $P \leq 0.05$. Data are expressed as mean \pm standard deviation (SD). 


\section{Conclusion}

Pulsed light exposure up to $120 \mathrm{~s}$ had an enhancing effect on the ORAC and total phenolic content of fresh blueberries, without degradative effects on other quality characteristics. The ORAC values and total phenolic content increased by nearly $75 \%$ and $48 \%$, respectively, relative to control. Anthocyanin production can be easily elicited and peaked within $30 \mathrm{~s}$ PL exposure and then level off for longer exposures up to $120 \mathrm{~s}$. There was no significant difference $(\mathrm{P} \leq 0.05)$ in the $\mathrm{SS}, \mathrm{pH}, \mathrm{TA}$, texture, color, and weight loss of the fresh blueberries up to $120 \mathrm{~s}$ PL exposure compared to control. The highest temperature rise was within $35.5^{\circ} \mathrm{C}$ at $120 \mathrm{~s}$ PL exposure. The increase antioxidant capacity and increase in polyphenolics may be attributed to the stimulatory effect of PL on PAL.

\section{References}

Agarwal, S. 2007. Increased antioxidant activity in cassia seedlings under UV-Bradiation. Biologia Plantarum, 51(1), 157-160. http://dx.doi.org/10.1007/s10535-007-0030-z

Ames, B. N. (1983). Dietary Carcinogens and Anticarcinogens. Science, 221(4617), 1256-1264. http://dx.doi.org/10.1126/science.6351251

Benkeblia, N. (2004). Antimicrobial activity of essential oil extracts of various onions (Allium cepa) and garlic (Allium sativum). Lebensmittel-Wissenschaft und-Technologie, 37(2), 263-268. http://dx.doi.org/10.1016/j.lwt.2003.09.001

Benvenuti, S., Pellati, F., Melegari, M., \& Bertelli, D. (2004). Polyphenols, Anthocyanins, Ascorbic Acid, and Radical Scavenging Activity of Rubus, Ribes and Aronia. Journal of Food Science, 69(3), 164-169. http://dx.doi.org/10.1111/j.1365-2621.2004.tb13352.x

Bialka, K., \& Demirci A. (2007). Decontamination of Escherichia coli 0157:H7 and Salmonella enterica on Blueberries Using Ozone and Pulsed UV-Light. Journal of Food Science, 72(9), 391-396. http://dx.doi.org/10.1111/j.1750-3841.2007.00517.x

Cao, G., Sofic, E., \& Prior, R. (1997). Antioxidant and prooxidant behavior of flavonoids: structure-activity $\begin{array}{llllll}\text { relationships. Free Radical Biology \& } & \text { Medicine, 22(5), }\end{array}$ http://dx.doi.org/10.1016/S0891-5849(96)00351-6

Cao, S., Hu, Z., Zheng, Y., \& Lu, B. (2010). Effect of BTH on Anthocyanin Content and Activities Related to Enzymes in Strawberry after Harvest. Journal of Agricultural Food Chemistry, 58, 5801-5805. http://dx.doi.org/10.1021/jf100742v

Duan, J., Wu, R., Bernadine, S., \& Zhao Y. (2011). Effect of edible coatings on the quality of fresh blueberries (Duke and Elliot) under commercial storage conditions. Postharvest Biology and Technology, 59, 71-79. http://dx.doi.org/10.1016/j.postharvbio.2010.08.006

Espín, J. C., García-Conesa, M. T., \& Tomás-Barberán, F. A. (2007). Nutraceuticals: Facts and Fiction. Phytochemistry, 68, 2986-3008. http://dx.doi.org/10.1016/j.phytochem.2007.09.014

Dixon, R., \& Paiva, N. (1995). Stress-Induced Phenylpropanoid Metabolism. The plant cell, 7, 1085-1097. http://dx.doi.org/10.2307/3870059

Halliwell, B. (1995). Antioxidant characterization: Methodology and mechanism. Biochemical Pharmacology, 49(10), 1341-1348. http://dx.doi.org/10.1016/0006-2952(95)00088-H

Heredia, J., \& Cineros-Zevallos, L. (2009). The effect of exogenous ethylene and methyl jasmonate on PAL activity, phenolic profiles and antioxidant capacity of carrots under different wounding intensities. Post Harvest Biology \& Technology, 51, 242-249. http://dx.doi.org/10.1016/j.postharvbio.2008.07.001

Huang, D., Ou, B., Hampsch-Woodill, M., Flanagan, J., \& Deemer, E. (2002). Development and Validation of Oxygen Radical Absorbance Capacity Assay for Lipophilic Antioxidants using Randomly Methylated B-Cyclodextrin as Solubility Enhancer. Journal of Agricultural Food Chemistry, 50, 4437-4444. http://dx.doi.org/10.1021/jf0201529

Jacob, R. A. (1995). The integrated antioxidant system. Nutrition Research, 15(5), 755-766. http://dx.doi.org/10.1016/0271-5317(95)00041-G

Krishnamurthy, K., Irudayaraj, J., Demirci, A., \& Yang, W. (2008). UV Pasteurization of Food Materials. Food Processing Operations Modelling: Design and Analysis, 281-302.

Kim, D., Chun, O., Kim, Y., Moon, H., \& Lee. C. (2003). Quantification of Phenolics and Their Antioxidant 
Capacity in Fresh Plums. Journal of Agricultural and Food Chemistry, 51, 6509-6515. http://dx.doi.org/10.1021/jf0343074

Lurie, S., Laamim, M., Lapsker, Z., \& Fallik, E. (2006). Heat treatment to decrease chilling injury in tomato fruit. Effects on lipids, pericarp lesions and fungal growth. Physiologia Plantarum, 100(2), 297-302. http://dx.doi.org/10.1034/j.1399-3054.1997.1000211.x

Moreno, M., Castell-Perez, M., Gomes, C., Da Silva, P., \& Moreira, R. (2007). Quality of Electron Beam Irradiation of Blueberries at Medium Dose Levels (1.0 - 3.2kGy). LWT-Food Science Technology, 40(7), 1123-1132. http://dx.doi.org/10.1016/j.lwt.2006.08.012

Oms-Oliu, G., Martin-Belloso, O., \& Solvia-Fortuny, R. (2010). Pulsed Light Treatments for Food Preservation. A Review. Food Bioprocess Technology, 3(1), 13-23. http://dx.doi.org/10.1007/s11947-008-0147-x

Perkins-Veazie, P., Collins, J., \& Howard L. (2008). Blueberry Fruit Response to Postharvest Application of Ultraviolet Radiation. Postharvest Biology and Technology, 47, 280-285. http://dx.doi.org/10.1016/j.postharvbio.2007.08.002

Rajchl, A., Cizkova, H., Voldrich, M., Jiruskova, M., \& Sevcik, R. (2009). Evaluation of shelf life and heat treatment of tomato products. Czech Journal of Food Science, 27, S130-133.

Sellappan, S., Akoh, C., \& Krewer, G. (2002). Phenolic compounds and antioxidant capacity of Georgia-grown blueberries and blackberries. Journal of Agricultural Food Chemistry, 50(8), 2432-2438. http://dx.doi.org/10.1021/jf011097r

Shriver, S., Yang, W., Chung, S-Y., \& Percival, S. (2011). Pulsed ultraviolet light reduces Immunoglobulin E binding to Atlantic white shrimp (Litopenaeus setiferus) extract. International Journal of Environmental Research. Public Health, 8, 2569-2583. http://dx.doi.org/10.3390/ijerph8072569

Silva, J., Marroquin, E., Matta, F., Garner, J., \& Stojanovic, J. (2005). Physiochemical, Carbohydrate and Sensory Characteristics of Highbush and Rabbiteye Blueberry Cultivars. Journal of the Science of Food and Agriculture, 85(11), 1815-1821. http://dx.doi.org/10.1002/jsfa.2083

\section{Copyrights}

Copyright for this article is retained by the author(s), with first publication rights granted to the journal.

This is an open-access article distributed under the terms and conditions of the Creative Commons Attribution license (http://creativecommons.org/licenses/by/3.0/). 